\title{
WATER TABLES CONSTRAIN HEIGHT RECOVERY OF WILLOW ON YELLOWSTONE'S NORTHERN RANGE
}

\author{
Danielle M. Bilyeu, ${ }^{1}$ David J. Cooper, ${ }^{2,3}$ and N. Thompson Hobbs ${ }^{1,2}$ \\ ${ }^{1}$ Natural Resource Ecology Laboratory, Colorado State University, Fort Collins, Colorado 80523 USA \\ ${ }^{2}$ Department of Forest, Rangeland, and Watershed Stewardship, Colorado State University, Fort Collins, Colorado 80523 USA
}

\begin{abstract}
Excessive levels of herbivory may disturb ecosystems in ways that persist even when herbivory is moderated. These persistent changes may complicate efforts to restore ecosystems affected by herbivores. Willow (Salix spp.) communities within the northern range in Yellowstone National Park have been eliminated or degraded in many riparian areas by excessive elk (Cervus elaphus L.) browsing. Elk browsing of riparian willows appears to have diminished following the reintroduction of wolves (Canis lupis L.), but it remains uncertain whether reduced herbivory will restore willow communities. The direct effects of elk browsing on willows have been accompanied by indirect effects from the loss of beaver (Castor canadensis Kuhl) activity, including incision of stream channels, erosion of fine sediments, and lower water tables near streams historically dammed by beaver. In areas where these changes have occurred, lowered water tables may suppress willow height even in the absence of elk browsing. We conducted a factorial field experiment to understand willow responses to browsing and to height of water tables. After four years of protection from elk browsing, willows with ambient water tables averaged only $106 \mathrm{~cm}$ in height, with negligible height gain in two of three study species during the last year of the experiment. Willows that were protected from browsing and had artificially elevated water tables averaged $147 \mathrm{~cm}$ in height and gained $19 \mathrm{~cm}$ in the last year of the experiment. In browsed plots, elevated water tables doubled height gain during a period of slightly reduced browsing pressure. We conclude that water availability mediates the rate of willow height gain and may determine whether willows grow tall enough to escape the browse zone of elk and gain resistance to future elk browsing. Consequently, in areas where long-term beaver absence has resulted in incised stream channels and low water tables, a reduction in elk browsing alone may not be sufficient for recovery of tall willow stands. Because tall willow stems are important elements of habitat for beaver, mitigating water table decline may be necessary in these areas to promote recovery of historical willow-beaver mutualisms.
\end{abstract}

Key words: alternative stable states; beaver; browsing; elk; hydrogeomorphic change; restoration ecology; riparian vegetation; trophic cascade; water availability; willow; wolf.

\section{INTRODUCTION}

Large herbivores can cause enduring changes in the structure and function of ecosystems (McInnes et al. 1992, Hobbs 1996, Frank and Evans 1997). Their impacts often extend beyond the direct effects of defoliation to include indirect influences on the physical environment, nutrient cycling, and the disturbance regime (Hobbs 2006). These indirect effects can cause herbivore-induced changes in ecosystems to persist even when herbivores are removed, creating alternative stable states maintained by altered feedbacks (Suding et al. 2004). For example, in African savannas, grazing by large herbivores interrupted the accumulation of fine fuels needed to carry ground fires; the absence of ground fire allowed trees to grow tall enough to escape the ground fires that resumed when grazers were removed

Manuscript received 7 February 2007; revised 4 June 2007; accepted 12 June 2007. Corresponding Editor: D. McKenzie.

3 Corresponding author.

E-mail: DavidC@cnr.colostate.edu
(McNaughton et al. 1988, van de Koppel et al. 1997). Similarly, in the Sahel region of Africa, cattle grazing caused shifts in vegetation cover from perennial grasses to unpalatable forbs and shrubs. A concomitant change in soil properties reduced infiltration of water, which depressed plant productivity and maintained community composition for decades after grazing was moderated (van de Koppel et al. 1997, Suding et al. 2004). In examples such as these, alternative, less desirable states were stabilized by altered feedbacks in the degraded ecosystem. Successful restoration in such situations requires understanding the nature of the altered feedbacks (Suding et al. 2004).

Accumulating evidence suggests that winter browsing by an abundant elk (Cervus elaphus L.) population caused a fundamental change in the state of the northern elk wintering range of Yellowstone National Park (YNP; Kay and Wagner 1994, Beschta 2003, Larsen and Ripple 2005, Wolf et al. 2007). In particular, elk browsing has been implicated in the disappearance of historically abundant stands of woody deciduous plants such as willow (Salix spp.), aspen (Populus tremuloides 
Michx.), and cottonwood (P. angustifolia James) during the past 80 years (Kay and Chadde 1991, Ripple and Larsen 2000, Larsen and Ripple 2005). Elk browsing of woody riparian vegetation likely was less intense during the early 1900s when wolves (Canis lupus L.) were abundant, increased in intensity after wolves were extirpated from the northern range (Beschta 2003, 2005, Larsen and Ripple 2003), and decreased again following wolf reintroduction in 1994 (Ripple and Beschta 2004a). However, it is unclear whether woody deciduous plant communities will be restored across the entire northern range by the recent moderation of elk browsing (Smith et al. 2003). Little attention has been given to the secondary effects of elk herbivory that may influence recovery even if herbivory is moderated.

One potentially important secondary effect of heavy elk herbivory is the competitive exclusion of beaver (Castor canadensis Kuhl). Heavy elk browsing may keep biomass from accumulating and create habitat that cannot support beavers (Baker et al. 2005, Hebblewhite et al. 2005) because beaver require large standing crops of woody deciduous plants for dam-building and foraging (Baker and Hill 2003). The presence or absence of beaver profoundly influences riparian habitats. Beaver dams increase water table height (Westbrook et al. 2006) stimulating willow productivity through increased water availability (Lindroth and Bath 1999). Beavers browse willows near dams intensively, but may temporarily abandon areas as resources become depleted, providing opportunities for willows to regain tall stature, produce seed (Baker et al. 2005), and establish seedlings on the bare, moist soils exposed as abandoned ponds drain (Cooper et al. 2006). The positive feedback between perennial or intermittent beaver presence, high water table, and high willow productivity forms a mutualistic interaction between beaver and willow (Baker et al. 2005) that can support vigorous willow communities in areas that may otherwise be hydrologically unsuitable for willow establishment and growth.

In Yellowstone's northern range, damming by beavers was common in the early 1900s (Warren 1926), declined dramatically in the decades following wolf extirpation (Jonas 1955), and ceased entirely by the late 1980s (Consolo Murphy and Hanson 1990). Following wolf reintroduction in 1994, beaver reestablished bank dens along a few large streams in the northern range, particularly the Lamar River and Slough Creek (Smith et al. 2003). However, beaver are not currently active along the numerous small streams where their dams historically had a large influence on floodplain hydrologic and geomorphic processes, such as Blacktail Deer Creek, Lost Creek, and Elk Creek. Decades of beaver absence in these areas allowed stream banks to erode and streams to incise through up to $2 \mathrm{~m}$ of fine-grained mineral sediments (Wolf et al. 2007). Stream incision has lowered water tables on adjacent floodplains, which could limit willow growth. Because beaver in Yellowstone are largely dependent on willow (Smith et al.
1996), this could limit or preclude beaver reestablishment. Newly created feedbacks between the declining water table, short willows, and beaver absence may have stabilized an alternative state of suppressed willow in these areas (Wolf et al. 2007).

All but one of the studies to date documenting wolfinduced willow recovery (Ripple et al. 2001, Beschta 2003, Ripple and Beschta 2003, 2004b) have been conducted along the few large, low-gradient streams that were never hydrologically influenced by beaver, because they are too wide for beavers to dam. Rivers of this size account for $\sim 23 \%$ of the total length of streams larger than first order on the northern range. The one study on smaller streams used comparative photographs to conclude that willow height had recovered in an area potentially influenced by beaver (Ripple and Beschta 2004a). However, the photos were mismatched by season; the pre-wolf picture was taken in late winter before bud break and after months of heavy browsing, while the post-wolf picture was taken at the end of the growing season following a full summer of stem growth (Fig. 1a, b). Because willow stems may grow a meter or more in height in a single growing season, and nearly all browsing occurs during winter, mismatching seasons in comparative photographs can produce erroneous conclusions. Comparative photographs with the order of seasons reversed, but within one post-wolf year (Fig. 1c, d), demonstrate that much of the apparent willow recovery was a seasonal effect.

To determine whether reduced elk browsing is sufficient for willow recovery in areas where beaver historically controlled the stream and floodplain hydrologic regime, we implemented a replicated, factorial experiment within Yellowstone's northern range. We manipulated the water table by constructing simulated beaver dams, and the influence of elk browsing by excluding elk herbivory with exclosures. We measured the height responses of three willow species common in our study areas, Salix bebbiana Sarg., S. boothii Dorn, and $S$. geyeriana Anderss., all of which may reach 3-5 m tall under normal conditions (Brunsfeld and Johnson 1985), to these treatments over a five-year period. Willow height is a critical response in these riparian ecosystems, because tall willows are more likely to supply the large standing crops required by beaver, and because a willow canopy $>200-250 \mathrm{~cm}$ tall may escape browsing by elk (Keigley and Frisina 1998), thereby reducing elk/beaver competition. In this paper we address the following questions: (1) Does water table depth limit willow height increases in the absence of browsing? and (2) Does water table depth influence willow height gain under changing ambient browsing pressure?

\section{Methods \\ Study area}

Our study sites were located in the northern range of Yellowstone National Park (YNP), USA, a 100000 - 


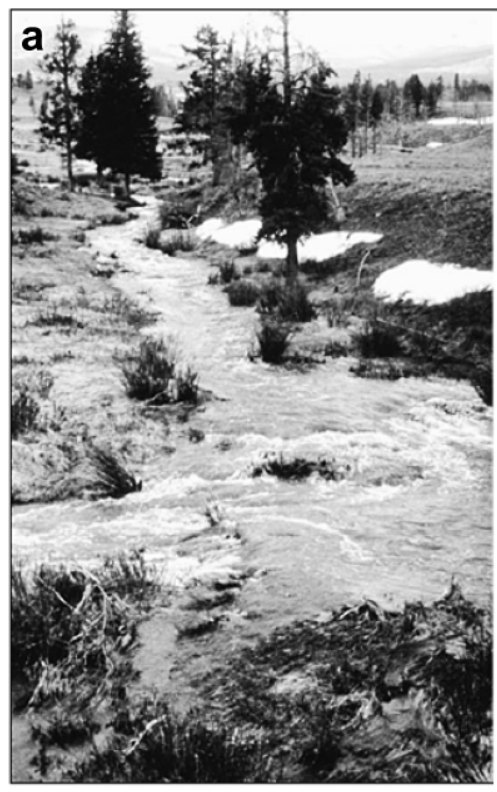

Spring 1996

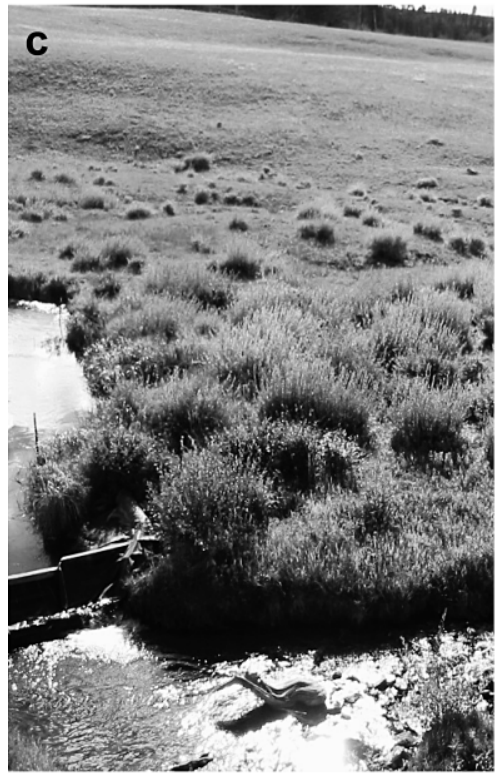

Summer 2004

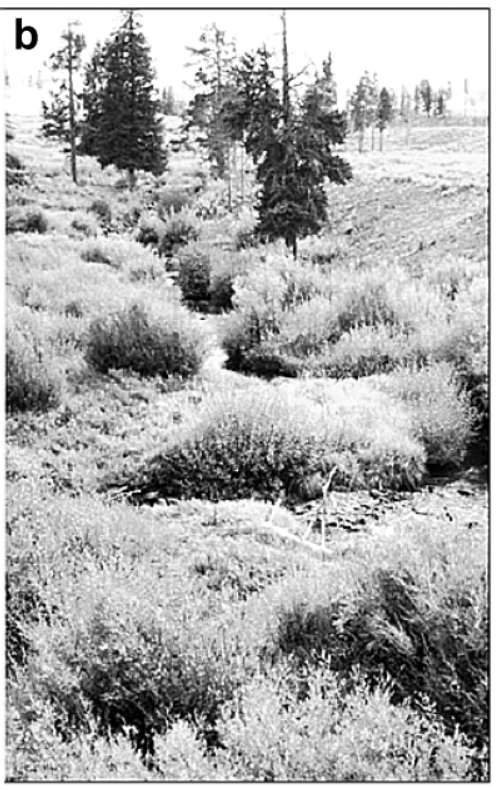

Summer 2002

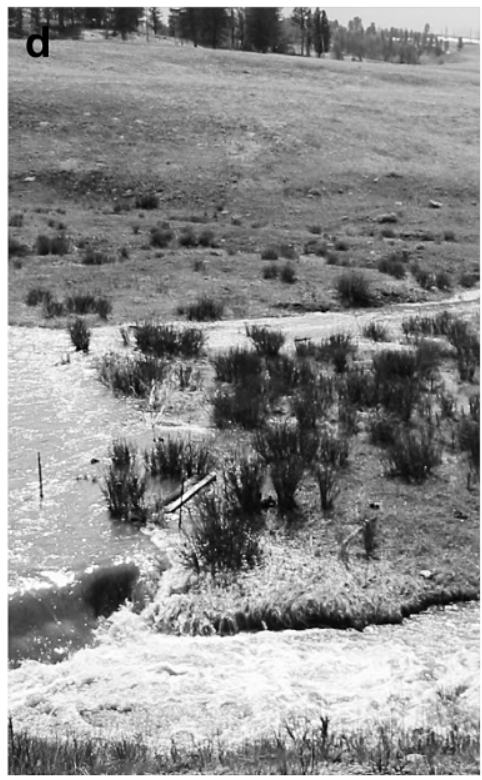

Spring 2005

FIG. 1. Top panels: photographs used to demonstrate that willows post-wolf (2002, panel b) had recovered in comparison to their pre-wolf condition (1996, panel a) on Blacktail Deer Creek, Yellowstone, National Park, USA. Lower panels: photographs taken $1.6 \mathrm{~km}$ upstream of those in the top panels, with the order of seasons reversed with respect to that of years. Some of the recovery implied in top panel photographs is actually a seasonal effect, because willows grow substantially over the course of a single growing season, and nearly all herbivory occurs over winter. Top panel photographs are reproduced from Ripple and Beschta (2004a), with permission from the American Institute of Biological Sciences.

hectare (ha) area used intensively by Yellowstone's largest elk herd during winter (Houston 1982; Fig. 2). Elevation spans $1925-2000 \mathrm{~m}$. Climate is semiarid; the area receives $260 \mathrm{~mm}$ of precipitation annually, 45-65\% of which falls during the growing season (Despain 1987). The landscape is formed of rolling hills of glacial till dominated by Artemisia tridentata Nutt. with an understory of Elymus smithii Rydb. and several other species of cool season grasses. Interspersed among the hills are small wetlands and wet meadows, dominated by Carex aquatilis Walenb. and the willows S. planifolia Pursch var. planifolia and $S$. wolfii Bebb. Higher elevations, particularly north-facing exposures, support stands of conifers (Pseudotsuga menziesii Mirb., Picea 


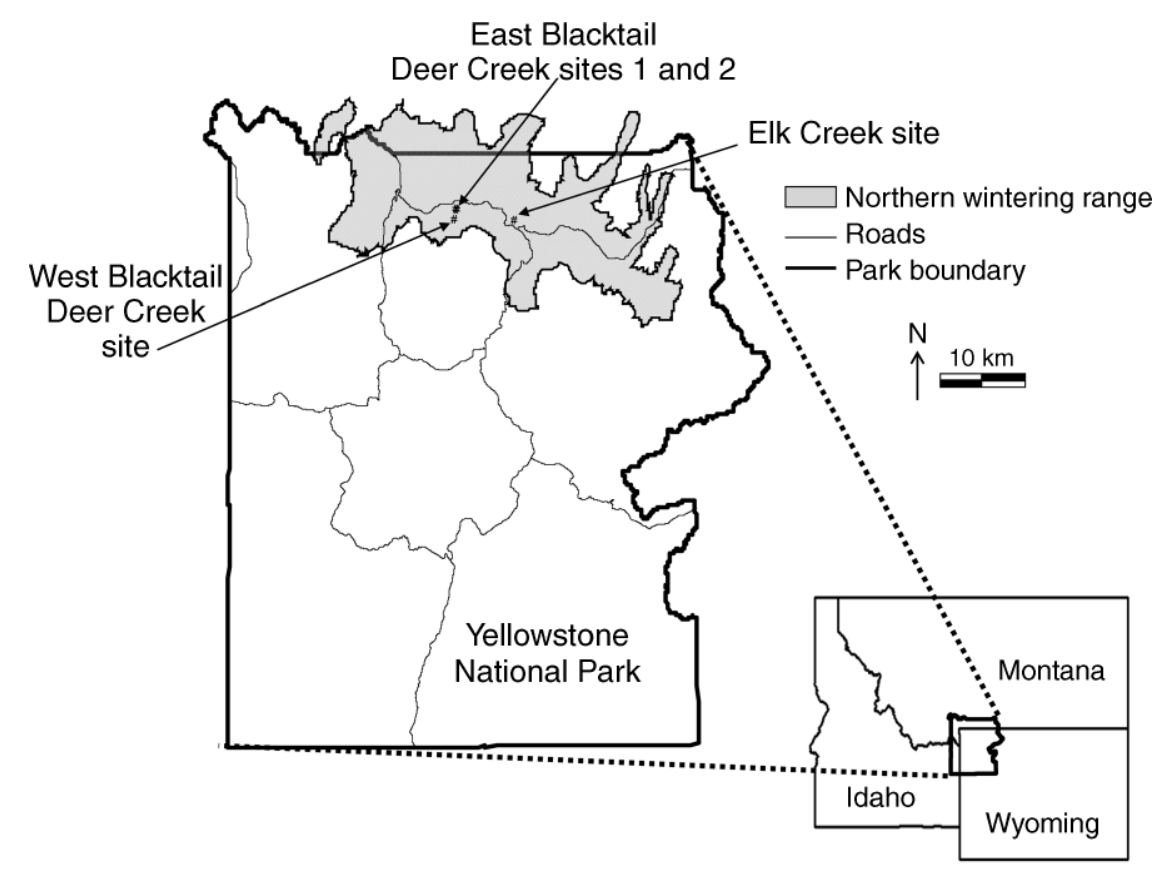

FIG. 2. Location of experimental sites within the Yellowstone northern elk wintering range.

engelmanni Parry ex Engelm., Abies lasiocarpa (Hook.) Nutt., and Pinus contorta Dougl. ex Loud. var. latifolia Engelm. ex Wats.) as well as Populus tremuloides in a patchy distribution (Houston 1982).

We chose study sites within the northern range located on terraces adjacent to third or fourth order streams that had experienced recent declines in the local water table, as evidenced by stream downcutting through previously inundated, gleyed, and mottled soils, and/or historical record of previous beaver ponding (Warren 1926, Jonas 1955). Ambient water tables in our study plots were $<0.5 \mathrm{~m}$ below the surface in the spring, dropping to 1-2 $\mathrm{m}$ in late summer. The growth form of all willows in our study plots at the start of the experiment was short (30-60 cm tall in spring) with browsed shoot stubs that had died back to the bud scar, indicating a history of heavy browsing (Keigley and Frisina 1998).

\section{Experimental design}

We conducted a factorial, randomized complete block experiment with four replicates on three small streams in the northern range (Fig. 2). Treatments included two levels of browsing by large herbivores (ambient and absent) crossed with two levels of water table (ambient and elevated; see Plate 1). Plots averaged $10 \times 20 \mathrm{~m}$ in size. During summer of 2001, we constructed $2.4 \mathrm{~m}$ high exclosures from steel fencing strung between wooden posts and reinforced with steel t-posts. Dams were constructed in fall of 2001 directly downstream from or adjacent to plots that had been selected to receive elevated water tables. Dams consisted of pine logs and square timbers that completely filled the stream channel.
Pond liner covered the structure and was secured to the streambed upstream of the dams to prevent water flow under or around the sides of the dam.

\section{Sampling}

In the fall of 2001 we selected seven plants per species per plot for permanent tagging using a systematic, spatially stratified protocol. The total number of plants of each species in each plot was counted. This number was divided by seven to determine the fraction of plants of each species to tag. The plot was divided into $1 \mathrm{~m}$ wide strips, and all plants were ordered according to their position on each strip. Strips were then walked and plants were tagged according to the predetermined fraction for each species; for instance, if the fraction of plants to tag was calculated as one-fourth, then every fourth plant encountered was tagged. Each plant consisted of a spatially discrete group of stems; stems were defined as portions of the plant emerging from the ground surface. Within each plant, three stems were selected and tagged using a game spinner placed over the center of the plant. Stem selection was stratified according to location within the plant, so that stems from the center, edge, and halfway between center and edge were equally represented. Each year, additional two-year-old stems were tagged on plants noted as having a large percentage of new stems the prior year. The number tagged each year was calculated so that the proportion of two-year-old stems tagged equaled that of older stems on the plant. This ensured that the average age of tagged stems did not increase with time, while preventing the tagging of first-year stems, which 


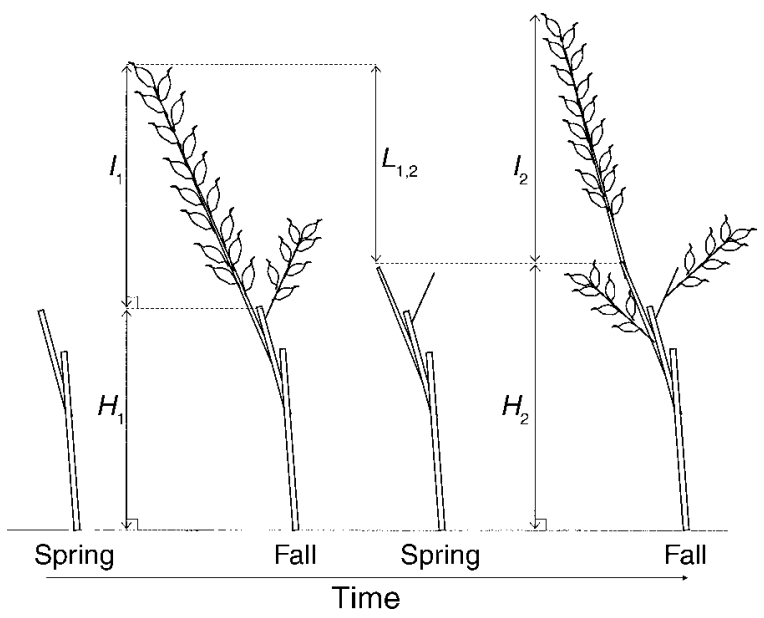

FIG. 3. Height measurements taken in the factorial experiment. Spring height $(H)$ is identified in the fall by finding the maximum height of bud scars on the plant. Summer height increment $(I)$ is the difference between total height and $H$. Height loss over the winter $\left(L_{1,2}\right)$ is calculated as $\left(I_{1}+H_{1}\right)-H_{2}$.

experience high mortality. We monitored $\sim 100$ stems per species at each of four replicate sites.

\section{Browsing intensity}

We quantified browsing intensity outside exclosures as the percentage of current annual growth (CAG) consumed using the biomass comparison method (Bilyeu et al. 2007) on all tagged stems each year from 2003 to 2005. This method compares estimates of stemlevel CAG in the fall, prior to browsing, with estimates of CAG remaining on the stem in the spring, after browsing. In the fall, CAG was estimated by measuring lengths of current-year shoots, calculating their mass (excluding leaves) via a length-dry mass regression $\left(r^{2}>\right.$ 0.96; Appendix), and summing shoot mass for all tagged stems in each plot. In the spring, similar calculations allowed estimation of mass of intact shoots, and mass of partially consumed shoots is estimated via a multiple regression using base diameter and the difference between browse point and base diameter $\left(R^{2}>0.85\right.$; Appendix). Mass of intact shoots and browsed shoot stubs was summed for each plot and provides an estimate of the fraction of prior season's CAG remaining in the plot. Browsing intensity is reported as one minus this fraction. This method has been shown to be more accurate than methods that take simple averages of twig-level consumption estimated from browse-point diameters, which tend to underestimate browsing intensity (Bilyeu et al. 2007).

\section{Water table depth}

To monitor the effect of our dam treatment on the water table depth, we installed two to six groundwater monitoring wells in each plot in July and August of 2001. Wells were constructed of slotted 3.2-cm PVC pipe and were installed by hand augering to a depth $\sim 30 \mathrm{~cm}$ below the water table, $120-280 \mathrm{~cm}$ deep. Following installation, wells were pumped dry several times to ensure proper flow between the well and adjacent soil. We recorded water levels approximately every two weeks during the growing season using an electric tape.

\section{Willow height}

Height responses were measured on the 28 tagged plants per species in each replicate site in all years of the experiment. In order to ensure that tagged plants mimicked untagged ones, heights of all plants in all plots were measured in years 2002-2005. We found no difference in average heights between tagged and untagged plants for all species $(P>0.42)$. We report here height responses of tagged plants.

In our study area, nearly all browsing occurs during winter and all growth occurs during summer. Because our study species may grow up to $1 \mathrm{~m}$ during a single season, willow height in the fall contains a sizable, variable fraction of growth that has not yet been exposed to browsing. Therefore, fall height is nearly always taller than height the following spring. Although previous researchers have reported late summer or fall height (Singer et al. 1994), we chose to track height changes through time using height in spring $(H)$ in order to avoid inclusion of the variable fraction that may soon be lost over winter (Fig. 3). We measured $H$ in each plot each year by finding the maximum perpendicular height of current year bud scars on the plant in late August (Keigley and Frisina 1998).

Although treatment effects on $H$ are most critical for assessing long-term willow responses, treatment effects on summer height gain ( $I$; Fig. 3) are also of interest, both as a rough measure of plant vigor and because height gained each summer constrains annual increases in $H$. Analysis of treatment effects on $I$ are complicated because we expected treatments, particularly exclosures, to affect tissue loss, and willows are known to compensate for loss by growing thicker, longer shoots (Peinetti et al. 2001). We were primarily interested in the effect of treatments on $I$ independent of those mediated by height loss; we sought to quantify treatment effects on the shape of the compensation response. Therefore, we also quantified winter height loss $(L)$, due to either browsing or twig shedding, which commonly occurs in Salix species during dormancy (Raven 1992; Fig. 3). We averaged responses over each plot for each species before analysis.

\section{Statistical analysis}

Treatment effects on $H$ were analyzed using repeatedmeasures ANCOVA in SAS PROC MIXED (SAS Institute 2002-2003) for a randomized complete block design with a repeated-measures structure. An autoregressive (lag $=1)$ covariance parameter was significant and therefore retained in the model. Pretreatment (2001) data for each response were included as a covariate. The two treatments, their interaction, treatment by year 
TABLE 1. Summary of functional forms for alternative Michalis-Menton models of summer height increment $(I)$ in terms of winter height loss $(L)$ of willows in the northern range of Yellowstone National Park, USA.

\begin{tabular}{ll}
\hline \multicolumn{1}{c|}{ Model description } & Equation \\
\hline No treatment effects & $I=\operatorname{int}+\left(\frac{L \times h_{\max }}{k+L}\right)$ \\
Treatment effects on intercept only & $I=\operatorname{int}+T+\left(\frac{L \times\left(h_{\max }-T\right)}{k+T+L}\right)$ \\
Treatment effects on intercept and & $I=\operatorname{int}+T+\left(\frac{L \times h_{\max }}{k+L}\right)$ \\
Treatment effects on asymptote only &
\end{tabular}

Note: In models with treatment effects, $T$ represents the effect of either dam or exclosure treatment; int represents the $y$-intercept.

interactions, and a three-way interaction between both treatments and year were included as potential fixed effects. We assumed that there were no block by treatment interactions. Interaction terms were dropped from the model when nonsignificant at $\alpha=0.05$ level. We report means of significant effects with $95 \%$ confidence limits.

Assessing how treatments altered the shape of the relationship between $I$ and $L$ required a different approach. We used information theoretics (Burnham and Anderson 2002) to compare the strength of evidence for alternative models of $I$ in terms of $L$ based on a Michalis-Menton function (Table 1), reasoning that because plant growth cannot increase without bound, a saturating function is more biologically realistic than a linear model. The parameters are interpretable: the $y$-intercept (int) describes the height increment we predict in the absence of browsing or twig shedding, and the asymptote $\left(h_{\max }\right)$ represents the plant's maximum capacity to compensate for height loss. To formulate candidate models we allowed each of the two treatments to alter the curve three ways: by influencing the intercept, the asymptote, or both (Table 1). This difference was achieved by altering the way the models were formulated, without adding or deleting parameters (Table 1). We also tested a null model with no treatment effects, for a total of seven models. We compared the strength of evidence in the data for these models using Akaike's Information Criterion, adjusted for small sample size $\left(\mathrm{AIC}_{\mathrm{c}}\right.$; Burnham and Anderson 2002). The lowest $\mathrm{AIC}_{\mathrm{c}}$ indicates the "best" model out of the tested set. However, because the scores are based on a given data set, there is some uncertainty that the same model would emerge as best if the models were tested with different data. We quantified this uncertainty by calculating a $w_{r}$ value for each model, which may be thought of as the "probability" that a given model would have the lowest $\mathrm{AIC}_{\mathrm{c}}$ score if tested with many data sets (Burnham and Anderson 2002). $\mathrm{AIC}_{\mathrm{c}}$, maximum likelihood estimates of model parameters, and confidence limits on model parameters were obtained by nonlinear fitting in SAS PROC NLMIXED. We assumed a normal error distribution and verified this assumption by examining histograms of residuals. For the best approximating model, we report parameter estimates with $95 \%$ confidence limits (hereafter CL).

\section{RESUlts}

Water table depth and browsing intensity

Dams elevated water table depth by an average of $0.37 \mathrm{~m}$ during the growing season (Table 2), but the effect was as large as $0.90 \mathrm{~m}$ in August in some years (Fig. 4). The water table decline late in the growing season was attenuated in dammed plots, a pattern similar to that observed for natural beaver dams in the Colorado Rocky Mountains (Westbrook et al. 2006).

Exclosures successfully prevented browsing by large herbivores during the study period. Outside exclosures, browsing removed $70 \% \pm 2 \%$ (mean $\pm \mathrm{SE}$ ) of current annual growth (CAG) in the winter of 2002-2003. Browsing intensity in the winters of 2003-2004 and 2004-2005 was $\sim 7 \% \pm 3 \%$ lower than that in 2002-2003 $(P=0.02$, Table 2$)$.

Earlier estimates of browsing intensity on the northern range were much lower; for example Singer 


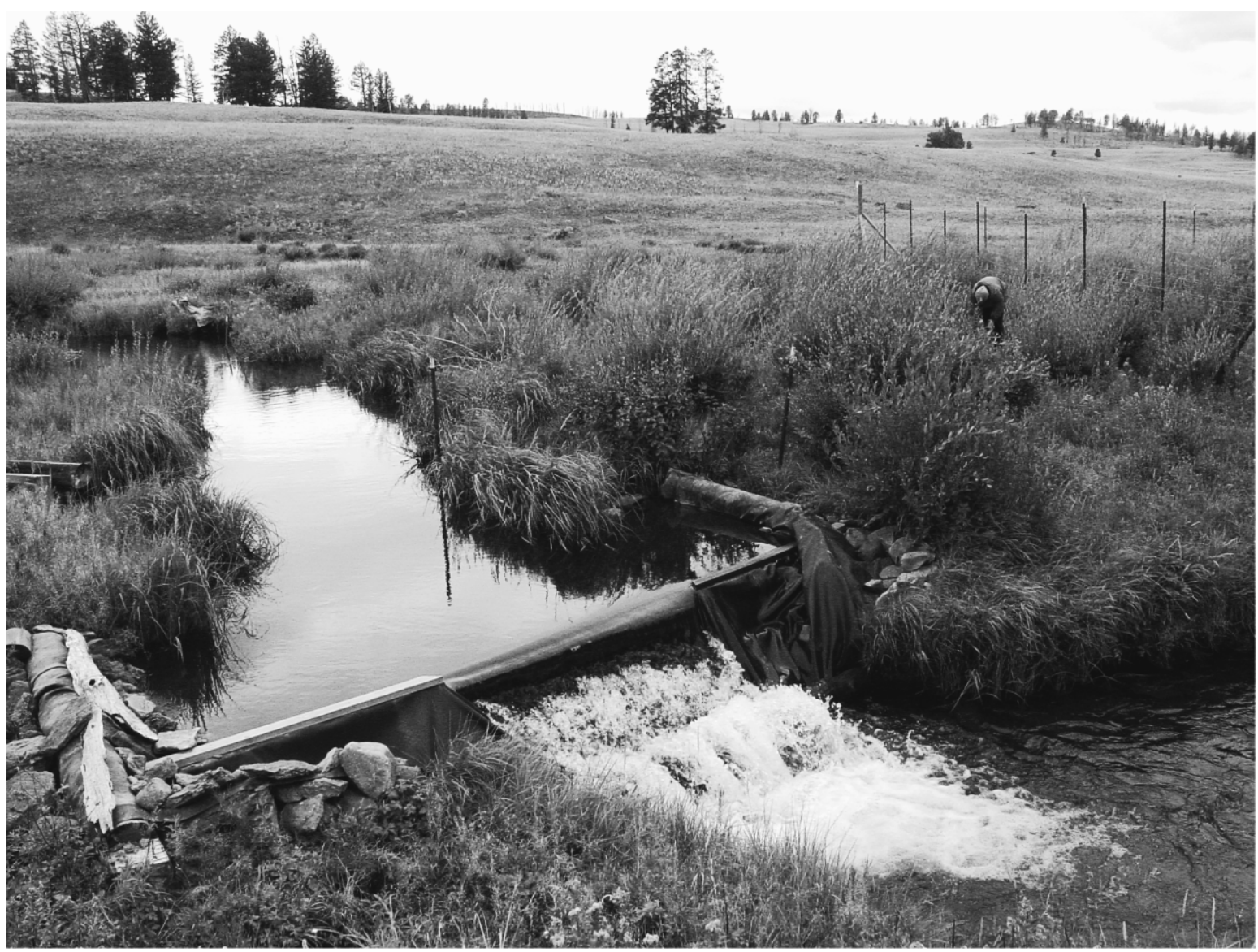

Plate 1. Upper of two dams at West Blacktail Creek, Yellowstone National Park (USA), the ambient-browsing, elevatedwater-table plot (to the left of the person), and the absent-browsing, elevated-water-table treatment plot within the fenced exclosure (to the right of the person). Photo credit: D. J. Cooper.

et al. (1998) reported that $\sim 27 \%$ of CAG was consumed during the period 1993-1995. However, these estimates are not comparable because the earlier estimates were calculated as the average percentage of all shoots that were browsed, multiplied by the average proportion removed of individual browsed shoots (L. Zeigenfuss, personal communication). We have shown that because elk selectively browse larger shoots, this calculation underestimates browsing intensity in terms of biomass (Bilyeu et al. 2007). A clipping experiment designed to test multiple methods of estimating browsing intensity against known values revealed that a browsing intensity

TABLE 2. Summary of ecological conditions in the study sites.

\begin{tabular}{lccccc}
\hline \hline & & \multicolumn{3}{c}{ Ecological condition } \\
\cline { 2 - 6 } & $\begin{array}{c}\text { Browsing } \\
\text { intensity } \\
\text { (percentage } \\
\text { CAG consumed) }\end{array}$ & $\begin{array}{c}\text { Prior } \\
\text { winter } \\
\text { snow }(\mathrm{m})\end{array}$ & $\begin{array}{c}\text { Summer } \\
\text { rain } \\
(\mathrm{mm})\end{array}$ & $\begin{array}{c}\text { Ambient water } \\
\text { table depth } \\
\text { Year, 95\% CI } \\
\text { in parentheses) }\end{array}$ & $\begin{array}{c}\text { Dam effect } \\
(\mathrm{m}, 95 \% \text { CI } \\
\text { in parentheses) }\end{array}$ \\
\hline 2001 & & 3.5 & 85 & $-1.3(0.16)$ & $0.08(0.13)$ \\
2002 & $70 \pm 2$ & 3.8 & 90 & $-1.17(0.10)$ & $0.36(0.08)$ \\
2003 & $63 \pm 3$ & 4.0 & 58 & $-1.18(0.09)$ & $0.36(0.09)$ \\
2004 & $65 \pm 2$ & 3.6 & 124 & $-1.24(0.10)$ & $0.40(0.11)$ \\
2005 & 65 & 167 & $-1.08(0.06)$ & $0.37(0.06)$ \\
\hline
\end{tabular}

Notes: Snow and rain data are averages from NOAA weather stations in Tower Junction and Mammoth, Wyoming, USA. Browsing intensity is the percentage of prior growing season's growth consumed, averaged across species and study sites. Snow data are summed for October through May, and rain data are summed for June through August. Water table depths are averaged over all undammed plots $(n=8)$ for May through September, and dam effect is the average difference between dammed and undammed plots in those months. Dams were constructed in fall of 2001 ; therefore 2001 should be regarded as pretreatment data. "CAG" is current annual growth. 

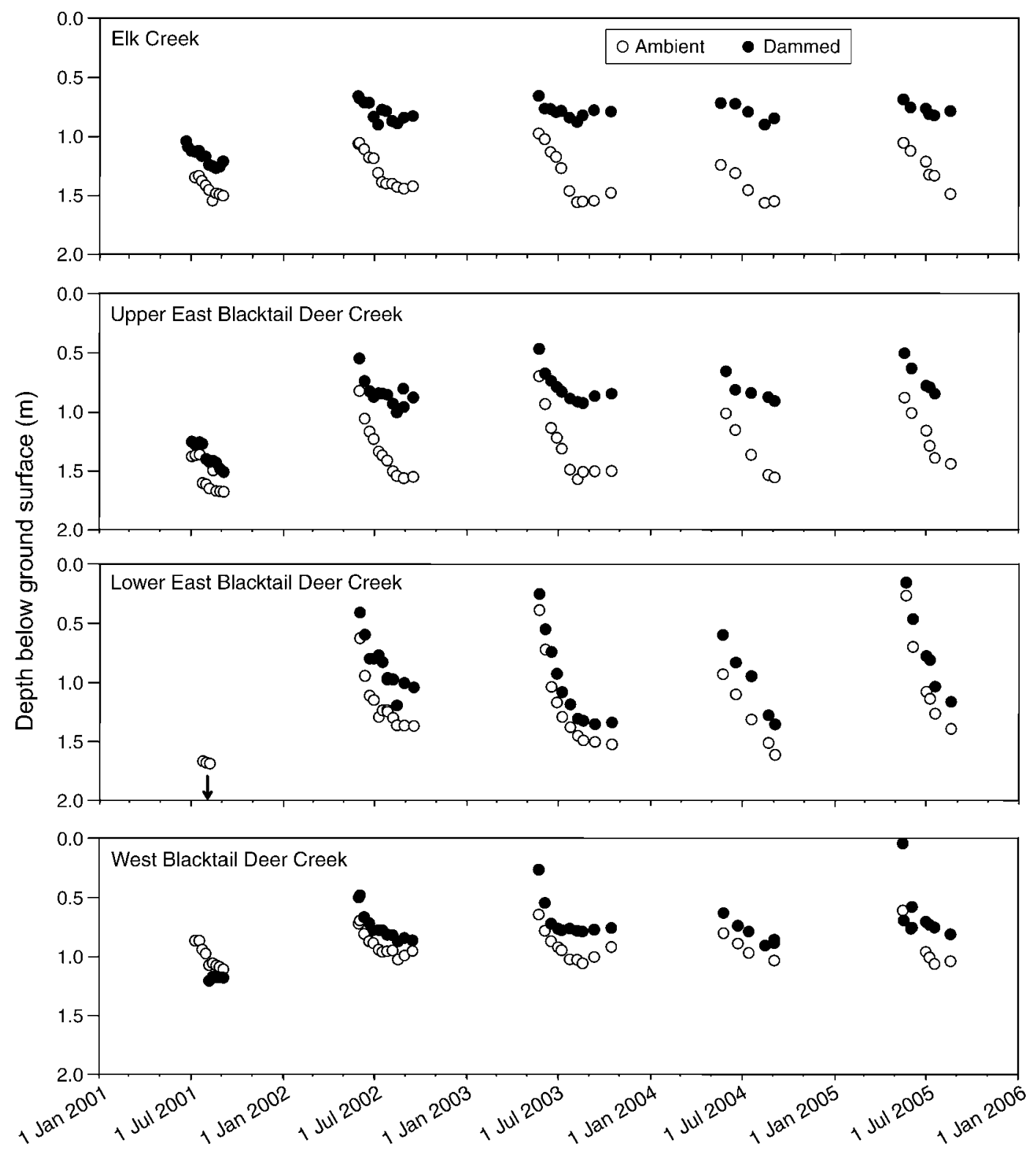

FIG. 4. Water table depths over the course of the experiment in water-ambient and water-elevated plots at Elk Creek, Upper East Blacktail Deer Creek, Lower East Blacktail Deer Creek, and West Blacktail Deer Creek. Each point is the average of 4-8 wells. Data from 2001 were taken before dams were installed. The arrow indicates that water table depths prior to dam installation at plots selected for damming treatment at Lower East Blacktail were deeper than $2.0 \mathrm{~m}$; monitoring wells dug to this depth prior to dam installation did not reach the water table.

estimate of $27 \%$ by the previously used method corresponds to $\sim 75 \%$ of CAG removed (Bilyeu et al. 2007). This comparison indicates that browsing intensity at our study sites during 2003-2005 was similar to or slightly lower than during the pre-wolf browsing period of 1993-1995 studied by Singer et al. (1998).

\section{Willow height}

The dam and exclosure treatments caused significant increases in spring stem height $(H)$ for all species (Fig. 5). After four years of treatment, the cumulative dam effect on $H$ was $42.9 \mathrm{~cm}$ (CL: 30.4, 55.3) for $S$. bebbiana, 27.8 cm (CL: 6.5, 49.0) for $S$. boothi, and $31.5 \mathrm{~cm}$ (CL: 20.2, 42.9) for $S$. geyeriana. The cumulative exclosure effect on $H$ was $46.8 \mathrm{~cm}$ (CL: $34.3,59.4$ ) for $S$. bebbiana, 54.1 cm (CL: 32.7, 75.4) for S. boothi, and $63.2 \mathrm{~cm}$ (CL: 53.0, 73.3) for $S$. geyeriana. There was no interaction between treatments for any species $(P>0.19)$.

There were significant main effects of year on $H$ for all species $(P<0.0001$; Fig. 5). Between 2001 and 2003, plants in undammed, unexclosed plots did not gain height $(P>0.37)$; however, between 2003 and 2005, 

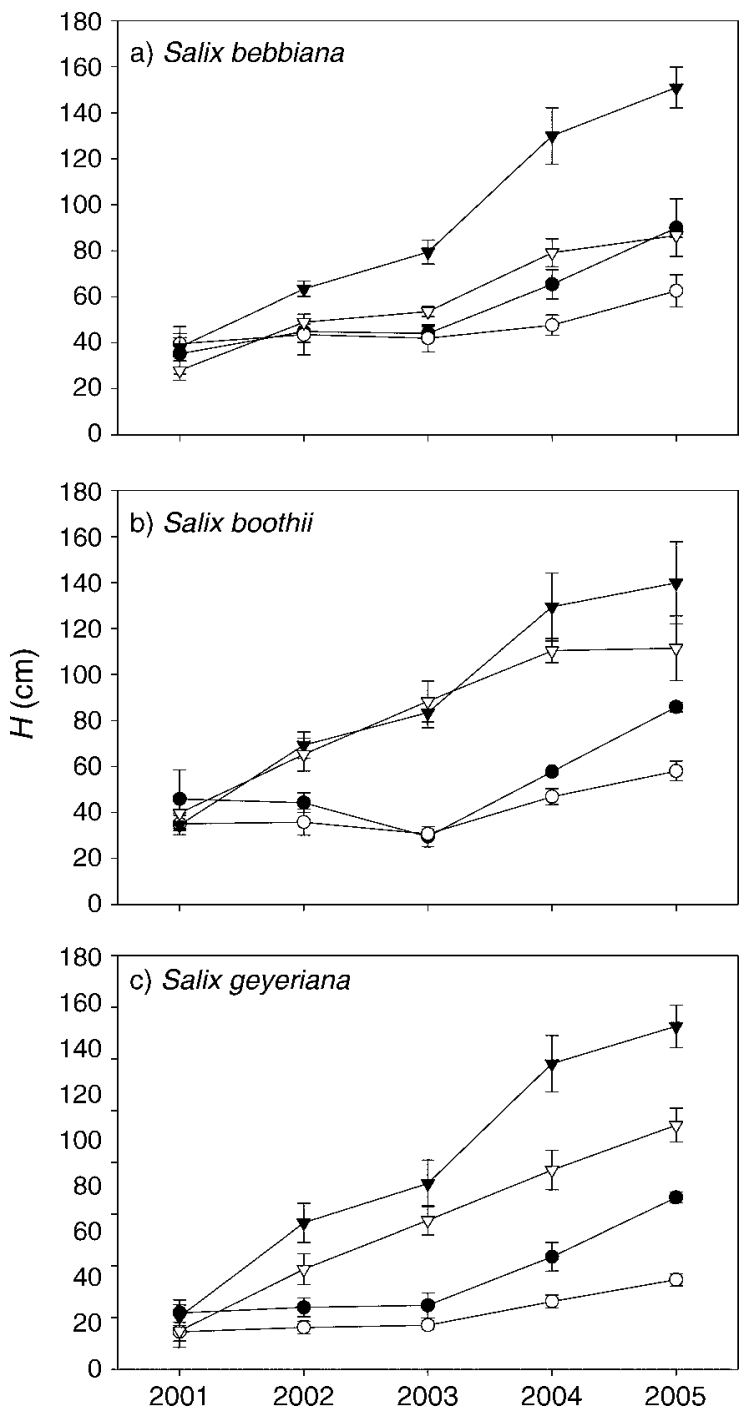

FIG. 5. Mean spring heights $(H)$ for three willow species in a factorial experiment for control plots (open circles), exclosed only plots (open triangles), dammed only plots (solid circles), and dammed and exclosed plots (solid triangles). Error bars are \pm SE. Data for 2001 are pretreatment data.

there was an across-species average gain of $20 \mathrm{~cm}$ in these plots $(P<0.02$; Fig. 5). The effect of dams on $H$ varied by year for all species $(P<0.004)$. Between 2001 and 2003, there was no significant effect of the dams on $H$ for any species (year $\times$ dam interaction for consecutive pairs of years 2001-2003, $P>0.11$; Fig. 5). However, between 2003 and 2005, the dam effect was $31.2 \mathrm{~cm}$ (CL: 18.5, 43.9) for $S$. bebbiana, 31.1 $\mathrm{cm}$ (CL: 15.8, 46.5) for S. boothi, and $24.0 \mathrm{~cm}$ (CL: 14.1, 33.9) for S. geyeriana. Therefore, the effect of the dams occurred largely in the last two years of the experiment.

The effect of exclosures also varied by year (year $\times$ exclosure interaction, $P<0.0001$, Fig. 5). Between 2002 and 2004, exclosures caused $H$ to increase every year for all species (year $\times$ exclosure interaction for consecutive pairs of years 2001-2004, $P<0.06$, Fig. 5). Between 2004 and 2005 the exclosure effect was -13.8 (CL: -26.2 , -1.5) for $S$. boothii, indicating that plants outside of exclosures had a greater $H$ increase than those inside exclosures (Fig. 5b). Exclosure effects between 2004 and 2005 were nonsignificant for $S$. bebbiana and $S$. geyeriana, indicating that plants inside exclosures had similar height gain as control plants $(P>0.30$; Fig. 5a, c).

\section{Compensation response}

Summer height increment $(I)$ increased with winter height loss ( $L$; Fig. 6), demonstrating that, as expected, willows compensated for higher levels of tissue loss by adding more height the following growing season. All
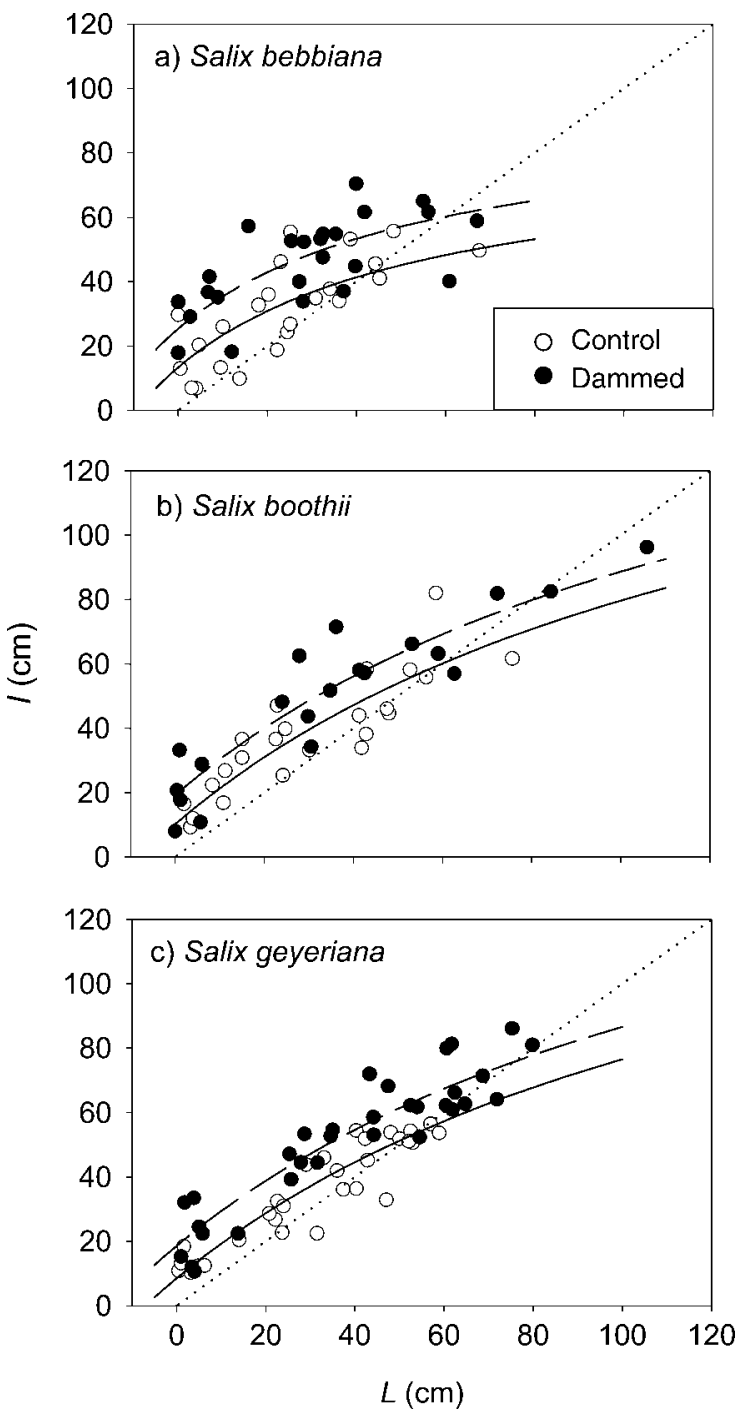

FIG. 6. Summer height increment $(I)$ for three willow species as a function of prior winter height losses $(L)$. Lowest $\mathrm{AIC}_{\mathrm{c}}$ model fit is shown: dashed lines, dammed plots; solid lines, control plots. Data for four years are included. All values above the dotted 1:1 line represent a net height increase. 
TABLE 3. Strength of evidence for competing asymptotic models of summer height gain in terms of winter height loss.

\begin{tabular}{|c|c|c|c|c|c|}
\hline $\begin{array}{l}\text { Species, } \\
\text { treatment } \\
\text { effect included }\end{array}$ & $\begin{array}{l}\text { Treatment influences } \\
\text { allowed on: }\end{array}$ & $\mathrm{AIC}_{\mathrm{c}}$ & $\Delta R$ & Likelihood & $w_{r}$ \\
\hline \multicolumn{6}{|l|}{ Salix bebbiana } \\
\hline Dam & intercept and asymptote & 359.7 & 0.00 & 1.00 & 0.71 \\
\hline Dam & intercept only & 361.7 & 2.01 & 0.37 & 0.26 \\
\hline Dam & asymptote only & 366.1 & 6.46 & 0.04 & 0.03 \\
\hline None & na & 371.8 & 12.10 & 0.00 & 0.00 \\
\hline Exclosure & asymptote only & 372.4 & 12.75 & 0.00 & 0.00 \\
\hline Exclosure & intercept and asymptote & 373.6 & 13.95 & 0.00 & 0.00 \\
\hline Exclosure & intercept only & 374.2 & 14.46 & 0.00 & 0.00 \\
\hline \multicolumn{6}{|l|}{ S. boothii } \\
\hline Dam & intercept and asymptote & 320.8 & 0.00 & 1.00 & 0.56 \\
\hline Dam & asymptote only & 321.9 & 1.10 & 0.58 & 0.32 \\
\hline Dam & intercept only & 324.7 & 3.95 & 0.14 & 0.08 \\
\hline None & na & 327.4 & 6.62 & 0.04 & 0.02 \\
\hline Exclosure & asymptote & 329.9 & 9.10 & 0.01 & 0.01 \\
\hline Exclosure & intercept only & 329.9 & 9.15 & 0.01 & 0.01 \\
\hline Exclosure & intercept and asymptote & 330.0 & 9.18 & 0.01 & 0.01 \\
\hline \multicolumn{6}{|l|}{ S. geyeriana } \\
\hline Dam & intercept and asymptote & 442.4 & 0.00 & 1.00 & 0.63 \\
\hline Dam & asymptote only & 443.9 & 1.48 & 0.48 & 0.30 \\
\hline Dam & intercept only & 446.7 & 4.25 & 0.12 & 0.07 \\
\hline Exclosure & asymptote & 459.0 & 16.63 & 0.00 & 0.00 \\
\hline None & na & 459.3 & 16.88 & 0.00 & 0.00 \\
\hline Exclosure & intercept and asymptote & 460.2 & 17.81 & 0.00 & 0.00 \\
\hline Exclosure & intercept only & 460.3 & 17.93 & 0.00 & 0.00 \\
\hline
\end{tabular}

Note: For all three study species, models allowing dams to influence both the intercept and asymptote had the most support in the data; "na" indicates not applicable.

models for $I$ in terms of $L$ with substantial support in the data included a dam effect, indicating that the ability of willows to compensate for height loss is influenced by an elevated water table (Table 3). The best-fit model for all three study species allowed the water table treatment to increase both the intercept and the asymptote of the function relating $I$ and $L$ ( $w_{r}$ values for the best approximating model: S. bebbiana, $0.71 ; S$. boothii, 0.56 ; S. geyeriana, 0.63 ; Fig. 6 ). For any given value of annual height loss $(L)$, this model predicts that dams would increase height gain the following growing season (I) by $12.0 \mathrm{~cm}$ (CL: $6.2,17.8$ ) for S. bebbiana, $9.0 \mathrm{~cm}$ (CL: 3.3, 14.7) for $S$. boothii, and $10.1 \mathrm{~cm}$ (CL: $5.6,14.3)$ for S. geyeriana (Fig. 6). The $y$-intercept in the absence of the dam treatment was 13.4 (CL: 5.6, 21.1) for $S$. bebbiana, 10.2 (CL: 2.6, 17.7) for S. boothii, and 8.5 (CL: $2.7,14.4)$ for $S$. geyeriana. Therefore, the effect of the dams at low levels of height loss was to roughly double $I$. No models including the effects of exclosures were supported by our data (Table 3 ).

\section{Discussion}

Our results show that higher water tables increased willow height both in the absence of browsing and under ambient browsing pressure. Thus, stream channel incision and deeper floodplain water tables caused by decades of beaver absence have retarded willow height recovery on small northern range streams. Our results also indicate that very heavy elk browsing suppresses willows, and that reducing or eliminating browsing promotes willow recovery. In our study area, tall willows appear likely to recover only through a combination of reduced elk browsing and increased water table.

Earlier research (Alstad et al. 1999, Zeigenfuss et al. 2002) examined the effect of water table manipulation and browsing on willows; however, inference in these studies was limited because their hydrologic treatments were of very small magnitude and effective for only a portion of the growing season (F. Singer, personal communication). Our study achieved a perennial water table treatment of substantial magnitude, enabling us to analyze willow responses to hydrologic changes approaching those formerly created by beaver in these areas (Warren 1926).

\section{Willow height in the absence of elk browsing}

After four years of protection, exclosed willows without the water table treatment remained remarkably short, and well within the height range that exposes stems to elk browsing. For example, in the last year of our study $S$. bebbiana plants averaged only $87 \mathrm{~cm}$ tall. At the average rate of height gain measured during this study, it would require 11 additional years of zero browsing for these plants to grow tall enough $(200 \mathrm{~cm})$ to escape the reach of elk. This is a minimum estimate because the rate of height gain appeared to slow over the course of the experiment. Exclosed S. bebbiana and $S$. boothii without the water table treatment had no height 
gain in the last year of our experiment $(P>0.19)$. Elevated water tables greatly increased the height of exclosed willows, and allowed all three Salix species to continue to gain height in the last year of the experiment $(P<0.07)$. For example, exclosed $S$. bebbiana with the water table treatment averaged $151 \mathrm{~cm}$ tall and would require only two additional years to reach $200 \mathrm{~cm}$ at the average rates of height gain measured.

\section{Water table effects on the compensation response}

In a comparison of alternative models relating summer height increment $(I)$ to winter height loss $(L)$, we found strong evidence that higher water tables increased the ability of willows to compensate for losses. Model comparisons revealed that this effect was important through the entire range of height loss, as models that allowed water table effects only when losses were low or high, but not both, performed poorly. At high levels of height loss, we observed a threshold, indicated by the intersection of the fit curves and the 1:1 line in Fig. 6, identifying the point where $I$ is sufficient to compensate for $L$. The water table treatment moved this threshold to the right, indicating that increased water allows plants to maintain height at higher levels of height loss. Because the water table treatment did not affect browsing intensity for any species $(P>0.30)$, we conclude that elevated water tables promoted willow height gain by allowing willows to grow longer shoots during the growing season, resulting in taller postbrowsing heights when the same proportion of CAG was consumed. This dynamic allowed browsed willows in dammed plots to gain $46 \mathrm{~cm}$ in spring height $(H)$ over the course of the experiment, while those in undammed plots gained only $22 \mathrm{~cm}$.

\section{Willow recovery across the landscape}

The high browsing intensities measured in our study areas in 2003, eight years after wolf reintroduction, suggest that wolf reintroduction has not caused a reduction in browsing intensity in all parts of the northern range. Wolves are thought to reduce elk browsing on willow largely by altering elk foraging behavior (Ripple and Beschta 2003, Fortin et al. 2005a), rather than by reducing elk population size. Willows cover only $0.4 \%$ of Yellowstone's northern range (Houston 1982), and it is likely that even low elk densities can maintain willows in a suppressed form. When the elk population was reduced by artificial culling in the 1960s to an average count of 5000 animals (Houston 1982), roughly half of the current population (Andersen 2005), no decrease occurred in the proportion of willow shoots browsed (Singer et al. 1994). Because wolves may lessen elk browsing intensity in areas of high predation risk, such as some valley bottoms that lack quick escape routes (Ripple and Beschta 2003), spatial variation in elk browsing intensity on the northern range is to be expected. The complete height suppression of browsed willows in the first three years of our study, both with and without the water table treatment, suggests that sufficient browsing pressure persists in some areas of the post-wolf landscape to greatly limit willow recovery.

Even in areas where predation risk is low and browsing intensity is typically high, however, winters with little snow cover may provide opportunities for willow height gain. Elk winter foraging behavior is influenced by snow depth (Fortin et al. 2005b), as grasses and herbaceous dicots are more available when the snowpack is thin, resulting in decreased browsing pressure on woody plants (Bellhouse and Rosatte 2005). A 35\% decrease in winter snowfall coincided with reduced winter browsing on willow in the last two years of our study (Table 2). The wolf population declined by $20 \%$ during this time (Smith 2005); therefore this change was not likely to be due to an increasing influence of wolves on elk foraging patterns. Whether temporary, weather-related depressions in browsing pressure result in lasting willow recovery depends on whether willows gain sufficient height to exceed the elk browsing height threshold before a winter with deep snow brings heavier browsing pressure. In our study, the period of reduced browsing pressure resulted in twice as much height gain for browsed plants receiving the water table treatment. We conclude that deep riparian zone water tables reduce the likelihood of ecosystem recovery under intermittently heavy browsing pressure.

Variability in willow height recovery due to variation in water table depth overlays that due to differences in elk browsing intensity. Where the water table depth has remained relatively stable even after the loss of most beaver, such as low gradient sections of the Lamar and Gallatin Rivers, willows may rapidly gain height in response to reduced elk browsing created by the wolf reintroduction. However, where loss of beaver dams has brought significant hydrologic change, such as much of Blacktail Deer Creek, Elk Creek, and Lost Creek, wolf reintroduction is less likely to be sufficient for willow recovery. We may view the landscape as a mosaic of areas differing in recovery potential, with the highest potential for recovery occurring in those areas with most intact hydrologic conditions and lowest browsing pressure.

Our efforts to simulate the hydrologic effects of beavers was limited by our research permit that allowed an increase in stream stage, but not overbank floods that could trigger channel avulsion. Natural beaver dams create overbank flooding and have a larger and more widespread effect on the water table than our experimental dams produced (Westbrook et al. 2006). Our data suggest that a more dramatic water table increase would provide additional benefit to willows. At our Elk Creek site, where the dam treatment led to a mid-July water table increase ranging from $0.6 \mathrm{~m}$ closest to the dam, to $0.05 \mathrm{~m}$ farthest from the dam, the magnitude of height gain for individual plants increased with larger water table treatment effects $\left(r^{2}=0.41, P=0.005, n=17\right.$ 
plants). If the water table treatment throughout our Elk Creek plot had been equal to that near the dam, we estimate that willows would have gained an average of $165 \mathrm{~cm}$, rather than the observed $135 \mathrm{~cm}$. By increasing the magnitude of individual plant response as well as the area of habitat affected, beaver would trigger more pronounced changes in landscape-scale vegetation structure than that demonstrated by our experiment.

\section{CONCLUSION}

Willow height gain along small, higher gradient streams on Yellowstone's northern range is strongly dependent on the hydrologic influence of beaver. The precise willow height, productivity, and standing crop required to support beavers in this landscape is an important remaining subject for research. However, because tall willow are important habitat elements for beaver, the magnitude of willow height limitation we observed suggests that lower water tables may limit or delay beaver reestablishment. Therefore, a feedback between low water table, reduced willow height gain, and beaver absence may retard ecosystem recovery, even if elk herbivory is moderated. We conclude that the short willow-beaver-absent landscape in Yellowstone's northern range has been stabilized by this feedback in some areas, specifically those areas of greatest hydrologic change. When alternative states become stabilized, ecosystems will not recover fully without mitigation of altered feedbacks (Beisner et al. 2003, Folke et al. 2004, Suding et al. 2004). Thus, full and timely restoration of the historical landscape may not be possible without actions to promote beaver reestablishment in addition to reducing elk use of willow. This may require physical changes to the stream channel, providing willow or aspen for beaver use in dam construction and for winter food, or a combination of these treatments.

\section{ACKNOWLedgments}

This work was funded by grants from the Biological Resources Divisions of the U.S. Geological Survey, Yellowstone National Park, and the National Science Foundation (Graduate Research Fellowship and Ecosystems Studies Program Award granted to Colorado State University). We thank the staff at the Yellowstone Center for Resources for logistical and technical support, particularly Roy Renkin, Mary Hektner, Glenn Plumb, and Christie Hendrix. We thank the Montana Conservation Corps, the Youth Conservation Corps, Target Volunteers, Paul Miller, and Evan Wolf for help in constructing exclosures and dams, many field assistants for help in taking willow measurements, and Heidi Steltzer for advice on the analysis. We dedicate this work to our colleague Francis J. Singer (1955-2005).

\section{Literature Cited}

Alstad, K. P., J. M. Welker, S. A. Williams, and M. J. Trlica. 1999. Carbon and water relations of Salix monticola in response to winter browsing and changes in surface water hydrology: an isotopic study using delta C-13 and delta O-18. Oecologia 120:375-385.

Andersen, R. J., editor. 2005. News and notes: 2004-05 count of Northern Yellowstone elk. Yellowstone Science 13:2.
Baker, B. W., H. C. Ducharme, D. C. S. Mitchell, T. R. Stanley, and H. R. Peinetti. 2005. Interaction of beaver and elk herbivory reduces standing crop of willow. Ecological Applications 15:110-118.

Baker, B. W., and E. P. Hill. 2003. Beaver (Castor canadensis). Pages 288-310 in G. A. Feldhammer, B. C. Thompson, and J. A. Champman, editors. Wild mammals of North America: biology, management, and conservation. Johns Hopkins University Press, Baltimore, Maryland, USA.

Beisner, B. E., D. T. Haydon, and K. Cuddington. 2003. Alternative stable states in ecology. Frontiers in Ecology and the Environment 1:376-382.

Bellhouse, T., and R. Rosatte. 2005. Assessment of the potential for negative interaction between re-introduced elk (Cervus elaphus) and resident white-tailed deer (Odocoileus virginianus) in their wintering areas in Ontario, Canada. Mammalia 69:35-56.

Beschta, R. L. 2003. Cottonwoods, elk, and wolves in the Lamar Valley of Yellowstone National Park. Ecological Applications 13:1295-1309.

Beschta, R. L. 2005. Reduced cottonwood recruitment following extirpation of wolves in Yellowstone's Northern Range. Ecology 86:391-403.

Bilyeu, D. M., D. J. Cooper, and N. T. Hobbs. 2007. Assessing impacts of large herbivores on shrubs: tests of scaling factors for utilization rates from shoot-level measurements. Journal of Applied Ecology 44:168-175.

Brunsfeld, S. J., and F. D. Johnson. 1985. Field guide to the willows of east-central Idaho. Bulletin number 39. University of Idaho, Moscow, Idaho, USA.

Burnham, K. P., and D. R. Anderson. 2002. Model selection and multimodel inference: practical information-theoretic approach. Second edition. Springer Verlag, New York, New York, USA.

Consolo Murphy, S., and D. D. Hanson. 1990. Current distribution of beaver in Yellowstone National Park. Pages 2-221-2-235 in Wolves for Yellowstone? A report to the United States Congress. Volume 2: research and analysis. National Park Service, Yellowstone National Park, Wyoming, USA.

Cooper, D. J., J. Dickens, N. T. Hobbs, L. Christensen, and L. A. Landrum. 2006. Hydrologic, geomorphic and climate controls on willow establishment in a montane ecosystem. Hydrological Processes 20:1845-1864.

Despain, D. G. 1987. The two climates of Yellowstone National Park. Proceedings of the Montana Academy of Science 47: $11-20$.

Folke, C., S. Carpenter, B. Walker, M. Scheffer, T. Elmqvist, L. Gunderson, and C. S. Holling. 2004. Regime shifts, resilience, and biodiversity in ecosystem management. Annual Review of Ecology Evolution and Systematics 35: 557-581.

Fortin, D., H. L. Beyer, M. S. Boyce, D. W. Smith, T. Duchesne, and J. S. Mao. 2005a. Wolves influence elk movements: behavior shapes a trophic cascade in Yellowstone National Park. Ecology 86:1320-1330.

Fortin, D., J. M. Morales, and M. S. Boyce. 2005b. Elk winter foraging at fine scale in Yellowstone National Park. Oecologia 145:335-343.

Frank, D. A., and R. D. Evans. 1997. Effects of native grazers on grassland $\mathrm{N}$ cycling in Yellowstone National Park. Ecology 78:2238-2248.

Hebblewhite, M., C. A. White, C. G. Nietvelt, J. A. McKenzie, T. E. Hurd, J. M. Fryxell, S. E. Bayley, and P. C. Paquet. 2005. Human activity mediates a trophic cascade caused by wolves. Ecology 86:2135-2144.

Hobbs, N. T. 1996. Modification of ecosystems by ungulates. Journal of Wildlife Management 60:695-713.

Hobbs, N. T. 2006. Large herbivores as agents of disturbance in ecosystems. Pages 291-288 in K. Danell, R. Bergstrom, P. Duncan, and J. Pastor, editors. Large herbivore ecology, 
ecosystem dynamics and conservation. Cambridge University Press, Cambridge, UK.

Houston, D. B. 1982. The northern Yellowstone elk: ecology and management. MacMillan, New York, New York, USA.

Jonas, R. J. 1955. A population and ecological study of beaver (Castor canadensis) of Yellowstone National Park. Thesis. University of Idaho, Idaho, USA.

Kay, C. E., and S. Chadde. 1991. Reduction of willow seed production by ungulate browsing in Yellowstone National Park. Pages 92-99 in W. P. Clary, E. D. McArthur, D. Bedunah, and C. L. Wambolt, editors. Proceedings Symposium on ecology and management of riparian shrub communities (Sun Valley, Idaho, 29-31 May). USDA Forest Service General Technical Report INT-289. Intermountain Research Station, Ogden, Utah, USA.

Kay, C. E., and F. H. Wagner. 1994. Historic condition of woody vegetation on Yellowstone's Northern Range: a critical evaluation of the "natural regulation" paradigm. Pages 151-169 in D. G. Despain, editor. Plants and their environments: Proceedings of the first scientific conference on the greater Yellowstone ecosystem. National Park Service Technical Report, Denver,Colorado, USA.

Keigley, R. B., and M. R. Frisina. 1998. Browse evaluation by analysis of growth form. Volume I: methods for evaluating condition and trend. Montana Fish, Wildlife, and Parks, Bozeman, Montana, USA.

Larsen, E. J., and W. J. Ripple. 2003. Aspen age structure in the northern Yellowstone ecosystem: USA. Forest Ecology and Management 179:469-482.

Larsen, E. J., and W. J. Ripple. 2005. Aspen stand conditions on elk winter ranges in the northern Yellowstone ecosystem, USA. Natural Areas Journal 25:326-338.

Lindroth, A., and A. Bath. 1999. Assessment of regional willow coppice yield in Sweden on basis of water availability. Forest Ecology and Management 121:57-65.

McInnes, P. F., R. J. Naiman, J. Pastor, and Y. Cohen. 1992. Effects of moose browsing on vegetation and litter of the boreal forest, Isle Royale, Michigan, USA. Ecology 73: 2059-2075.

McNaughton, S. J., R. W. Ruess, and S. W. Seagle. 1988. Large mammals and process dynamics in African ecosystems. BioScience 38:794-800.

Peinetti, H. R., R. S. C. Menezes, and M. B. Coughenour. 2001. Changes induced by elk browsing in the aboveground biomass production and distribution of willow (Salix monticola Bebb): their relationships with plant water, carbon, and nitrogen dynamics. Oecologia 127:334-342.

Raven, J. A. 1992. The physiology of Salix. Proceedings of the Royal Society of Edinburgh Section B: Biological Sciences 98:49-62.

Ripple, W. J., and R. L. Beschta. 2003. Wolf reintroduction, predation risk, and cottonwood recovery in Yellowstone National Park. Forest Ecology and Management 184:299313.
Ripple, W. J., and R. L. Beschta. 2004a. Wolves and the ecology of fear: Can predation risk structure ecosystems? BioScience 54:755-766.

Ripple, W. J., and R. L. Beschta. 2004b. Wolves, elk, willows, and trophic cascades in the upper Gallatin range of southwestern Montana, USA. Forest Ecology and Management 200:161-181.

Ripple, W. J., and E. J. Larsen. 2000. Historic aspen recruitment, elk, and wolves in northern Yellowstone National Park, USA. Biological Conservation 95:361-370.

Ripple, W. M., E. J. Larsen, R. A. Renkin, and D. W. Smith. 2001. Trophic cascades among wolves, elk and aspen on Yellowstone National Park's Northern Range. Biological Conservation 102:227-234.

SAS Institute. 2002-2003. SAS system for Windows. Version 9.1. SAS Institute, Cary, North Carolina, USA.

Singer, F. J., L. C. Mark, and R. C. Cates. 1994. Ungulate herbivory of willows on Yellowstone northern winter range. Journal of Range Management 47:435-443.

Singer, F. J., L. C. Zeigenfuss, R. G. Cates, and D. T. Barnett. 1998. Elk, multiple factors, and persistence of willows in national parks. Wildlife Society Bulletin 26:419-428.

Smith, D. W. 2005. Ten years of Yellowstone wolves, 19952005. Yellowstone Science 13:7-31.

Smith, D. W., S. Consolo Murphy, M. K. Phillips, and R. Crabtree. 1996. Beaver survey, Yellowstone National Park 1996. Report number YCR-NR-97-1. Yellowstone National Park, Wyoming, USA.

Smith, D. W., R. O. Peterson, and D. B. Houston. 2003. Yellowstone after wolves. BioScience 53:330-340.

Suding, K. N., K. L. Gross, and G. R. Houseman. 2004. Alternative states and positive feedbacks in restoration ecology. Trends in Ecology and Evolution 19:46-53.

van de Koppel, J., M. Rietkerk, and F. J. Weissing. 1997. Catastrophic vegetation shifts and soil degradation in terrestrial grazing systems. Trends in Ecology and Evolution 12:352-356.

Warren, R. E. 1926. A study of beaver in the Yancey region of Yellowstone National Park. Roosevelt Wild Life Annals 1: 13-191.

Westbrook, C. J., D. J. Cooper, and B. W. Baker. 2006. Beaver dams and overbank floods influence groundwatersurface water interactions of a Rocky Mountain riparian area. Water Resources Research 42:W06404 [doi: 10.1029/ 2005WR004560].

Wolf, E. C., D. J. Cooper, and N. T. Hobbs. 2007. Beaver, stream flow, and elk influence willow establishment and floodplain stability on Yellowstone's northern range. Ecological Applications 17:1572-1587.

Zeigenfuss, L. C., F. J. Singer, S. A. Williams, and T. L. Johnson. 2002. Influences of herbivory and water on willow in elk winter range. Journal of Wildlife Management 66: 788-795.

\section{APPENDIX}

A table of regression parameters for equations used in calculating browsing intensity in Yellowstone National Park, USA (Ecological Archives A018-002-A1). 